\title{
Research on Dynamic Mechanism of Trade Associations to Participate in Development of Modern Apprenticeship in China
}

\author{
Hongwei Cui \\ School of Finance, Jilin Business and Technology College, Changchun, Jilin Province, China \\ 434787877@qq.com
}

Keywords: Modern apprenticeship; Trade associations; Dynamic mechanism

\begin{abstract}
The State Council document, "the decision on accelerating the development of modern vocational education", puts forward that it is necessary to strengthen the position and role of the industry association in the development of vocational education, to give policy support to the industry organization and to strengthen the supervision of service, and to give the responsibilities to the industry organizations. The outline of the national medium and long term educational reform and development plan (2010-2020 years) also pointed out that the role of trade associations in education public governance should be brought into full play. Under this background, it is feasible and realistic to analyze the dynamic mechanism of trade associations' participation in the development of modern apprenticeship in China. This article, starting with the analysis of the background of the development of modern apprenticeship, discusses the necessity of participating in the modern apprenticeship system, and tries to put forward some countermeasures and suggestions to strengthen the industry association to participate in the development of the modern apprenticeship system.
\end{abstract}

\section{Introduction}

Modern apprenticeship is based on the concept of traditional apprenticeship. The modern apprenticeship system has inherited the teaching method of the apprentice, but has its own unique connotation. It integrates the characteristics of modern school education, but it is different from vocational education in school form. The relevant data show that there was little research on the modern apprenticeship in China before 2011, and from the 2012 work point of the Ministry of education in January 2012, it was proposed that the modern apprenticeship system has been greatly improved since the opening of the modern apprenticeship system. In September 2014, in the opinion of the Ministry of education on the pilot work of the modern apprenticeship, it was pointed out that "the gradual establishment of government guidance, industry participation, social support and modern apprenticeship with Chinese characteristics of two owners in enterprises and vocational colleges" has become a hot topic in the research of Vocational education. Since 2015, the modern apprenticeship system has been officially launched in China. The Ministry of education initially selected 165 units as the first batch of modern apprenticeship. In 2016, the Ministry of education conducted a review of the pilot units, 163 units approved the record, 1 units voluntarily applied for the abandonment of the pilot, and 1 units did not pass the audit. In 2017, the State Council issued the "13th Five-Year" promotion of employment plan, which put forward the pilot work on modern apprenticeship in an all-round way; in 2017, the Ministry of education pointed out the pilot of the second batch of modern apprenticeship with Chinese characteristics. Under this background, it is of certain significance to analyze the development of modern apprenticeship by trade associations. First, it is conducive to enriching the theoretical development of college development and modern vocational education. The development of colleges and universities is an important part of current education research. At the same time, vocational education is an important part of national education. It is not only to enrich the theory of vocational education and the development of colleges and universities, but also to enrich the theory of dynamic mechanism. Second, it is beneficial to broaden the theoretical research on the cooperation of stakeholders in vocational education. The study of this paper can further enrich the related content of vocational education 
cooperation, and provide a theoretical basis for the scientific and orderly development of the cooperation of professional education related stakeholders. Third, it is good for the theory to serve practice better. This paper studies the development motive of modern apprenticeship "China", which aims to provide a reference for the theory and practice of sustainable development of Higher Vocational Colleges with a view to the survival environment and long-term development of higher vocational colleges.

\section{The Necessity of Trade Associations to Participate in Development of Modern Apprenticeship in China}

The industry association is a self-regulated, nonprofit corporative for the maintenance of the interests of the industry. It serves and manages the business of the related industry. Trade associations have been playing a key role in the training of modern apprenticeship in western countries.

The Participation of Trade Associations in Modern Apprenticeship is a Form of Realizing Their Social Functions. The industry association is the representative of the industry enterprises in the boundary. Naturally, it has the advantage of coordinating the harmonization of many aspects, such as school, enterprise and government. It participates in the modern apprenticeship "China" development, and can perform a part of coordination and auxiliary functions, and play the role of "bridge", "bond" and "lubricant". Trade associations play an irreplaceable role in building smooth communication channels between governments, schools and enterprises. As an intermediary organization, the function of the trade association is basically around "providing services, reflecting demands and standardizing behaviors", which can provide services for personnel training. It has an absolute advantage to grasp the market information and has a congenital advantage for the collection of information in the industry. Therefore, the participation of the industry association in the modern apprenticeship system is a form of realizing its social function. The industry association participates in the education and supports the development of the enterprise from the link of human resources training. It can sum up the commonness and individuality in the information that the enterprises have defined for the talents. It greatly improves the efficiency of the information communication between the school and the enterprise, and reduces the standard of Vocational College and the standard of the enterprise. This difference alleviates the contradiction of talent cultivation, and helps to improve the employment rate of graduates in supporting the development of schools. In support of government work, it is conducive to promoting the development of the market economy; in the industry association itself, it is beneficial to enhance its reputation and reputation in the level of improving the social service capacity. Therefore, this coordination process is a multi win result.

The Participation of Trade Associations in Development of Modern Apprenticeship is an Inevitable Choice for the Development of Vocational Education. As a guiding force of management, trade associations participate in the development of modern apprenticeship in China, which is the inevitable result of the basic law of vocational education and its development. In the practice of modern apprenticeship in China, although enterprises have great demand for skilled talents, they seldom participate directly in them, which is mainly dominated by schools. The task and pressure on the job and pressure of the study of the job demand, collection, collation, analysis of the feedback of the enterprise, the ability to cultivate the target and the job, and the adjustment of the curriculum system are all completed by the school. Therefore, vocational education urgently needs an intermediary organization which is above the industry enterprise and understands the needs of the industry to coordinate guidance. The industry association should play the corresponding function and function, thus liberate the vocational colleges and better carry out the construction of the enterprise curriculum.

\section{The Way of Existing Trade Associations Participate in Vocational Education}

At present, China's trade associations participate in Vocational Education in the following ways: 
First, the vocational colleges and universities in order to survive, review the situation, actively seek the support of the industry association, respectively, as the location of the Secretariat of the industrial association of the industry association, the executive member or the member unit, so that the industry association has become the "interactive bridge" between the schools and the enterprises. With the help of the industry association, the professional construction of these vocational colleges, the construction of curriculum and the work of production, school and research have been greatly developed, and good results have been achieved. Second, trade associations and enterprises or vocational schools jointly founded vocational colleges. Third, trade associations holding vocational education and training institutions. Trade associations are non-profit organizations. The profit of establishing training schools is contrary to the nature of non-profit organizations. At present, the college of electronic information engineering of career academy, Wuhan city, has built up a modern apprenticeship pattern based on the characteristics of modern apprenticeship, based on the characteristics of the modern apprenticeship, based on the principal-agent chain structure in the school organization, as shown in Fig. 1. In this figure, it includes six main subjects of direct responsibility, such as government, industry association, vocational college, enterprise, master, student and so on. These subjects have different interest demands in the various operation links of modern apprenticeship and reflect different functional responsibilities at different levels.

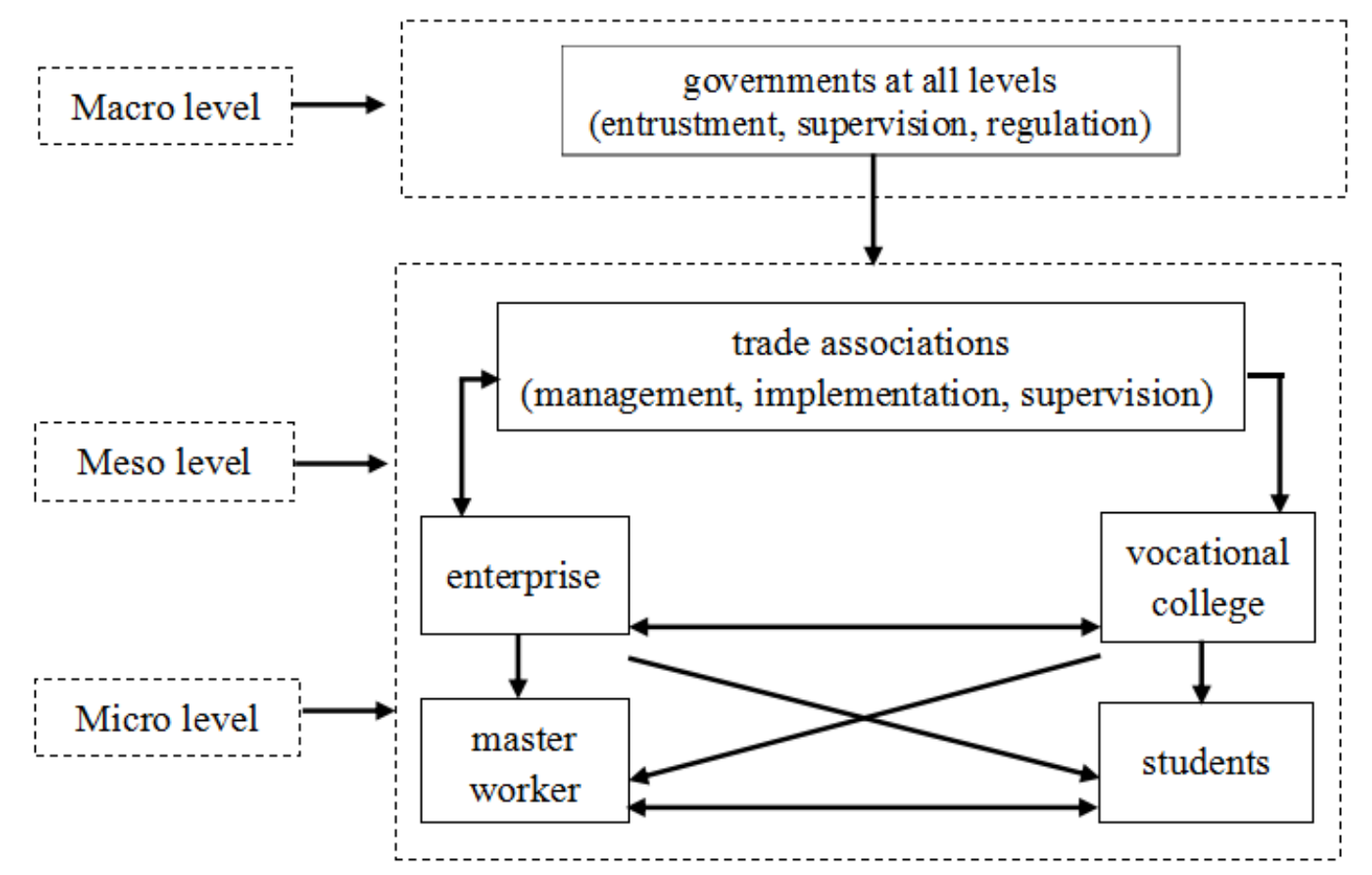

Figure 1. Finite The modern apprenticeship model of "Government Commission and Guild Agency"

Trade associations and enterprises or schools jointly set up vocational colleges or their own vocational training institutions, to a certain extent, as a bridge, promote the communication between schools and enterprises, and play a role for the development of vocational education, but this effect is very limited to the individual colleges and universities.

\section{Suggestions on Maintaining Trade Associations' Participation in Development of Modern Apprenticeship in China}

Many scholars have expounded their respective understanding of the dynamic mechanism from different angles. This article agrees with Hao Yingqi's exposition of the dynamic mechanism. Hao Yingqi believes that power mechanism is composed of three elements: power, responsibility and interest. Power is the foundation and guarantee of fulfilling responsibility. Interest is the essential 
pursuit of the enterprise and the initial source of power. Responsibility is the attachment point of power, and the enterprise realizes the organization goal by fulfilling its responsibility. Therefore, it is suggested to improve the power mechanism from three aspects: rights, responsibilities and interests.

Clear the Rights of the Industry Association in the Apprenticeship Reform. In order to give full play to the advantages of the industry association, it is necessary to clarify the functions of the trade associations in vocational education and protect their legitimate rights and interests in order to give full play to the advantages of the industry association. In order to give full play to the role of the industry association in the development of modern apprenticeship, we should clarify the responsibilities of the government departments, industry associations, vocational colleges and enterprises, and form a system and mechanism for clear division of labor, orderly cooperation and standard development. Specifically, when the relevant laws and regulations are revised, the state should make clear the legal status of the modern apprenticeship system and establish the cost sharing mechanism of the modern apprenticeship personnel training for the participation of the government, industry associations, enterprises, vocational colleges and other parties. In addition to the inherent authority, the industry association should also stipulate that it should accept government entrustment and supervision, be responsible to the government departments and participate independently in the research, management, supervision, decision-making and implementation of the modern apprenticeship reform. This will not only help reduce the resistance in modern apprenticeship reform, but also help the development of trade associations themselves.

Clear the Responsibility of the Industry Association in the Apprenticeship Reform. Although the industry association has no management power, it can build a platform for multi party cooperation and provide services for University, enterprise, government and multi party communication. As the coordinator of the school and enterprise cooperation, the industry association can not only guarantee the multiparty interests in the training process of the modern apprenticeship, but also make up for the lack of the current duties of the industry association and promote the harmonious development of the multi-party relations. It will bring great impetus to the further promotion of the modern apprenticeship system and cultivate high quality for our country. To make contributions to skilled professionals. Therefore, the industry association needs to change its own position in the development of the modern apprenticeship. For the differences and contradictions between the two sides of the school and enterprise, it can act as an intermediary regulator, effectively alleviate the problems existing in the school and enterprise cooperation, and help to adjust and deal with the misunderstandings of the two parties in time.

Clear the Interests Compensation of Trade Associations in Apprenticeship Reform. Trade associations manage internally funded funds, while externally express their interests to the government through communication and dialogue. The participation of trade associations in the reform of modern apprenticeship is an extension of their social service function and requires necessary capital input. As a public project, the modern apprenticeship reform, from the point of view of the government, should be supported by funds, especially the initial participation in the need for part of the funds to start, so the government should compensate and make clear the compensation. In order to promote the enthusiasm of the industry association in the reform of vocational education, the government can stipulate schools and enterprises to increase the legitimate income of trade associations in various forms.

\section{Project}

The youth project of education of the National Social Science Fund "Research on the Dynamic Mechanism of Trade Associations Participating in Modern

Apprenticeship" (CJA170261)

\section{References}

[1] Wenpeng Hu,libin Lu,jing Liu. Research on the impetus of trade associations to participate in 
the reform of modern apprenticeship system. Journal of Beijing Vocational College of Finance and Commerce. 2015 (12) .

[2] Yan Hu,xiaole Duan. Research on the role and location of trade associations in the modern apprenticeship mode. Journal of Management. 2016 (7) .

[3] Chuanwei Li,pengbo Yu.Pilot study on modern apprenticeship under the coordination of trade associations. Journal of Educational Assessment.2018 (4).

[4] Zhihua Zhai.Study on modern apprenticeship promotion strategy based on stakeholders.Journal of Vocational Education in Xinjiang.2017 (12).

[5] Huashan Zhan.Construction of interest conflict and balance mechanism in modern apprenticeship school enterprise cooperation.Journal of Education and Career.2017 (12).

[6] Min Jia.Research on industry associations participation modern vocational education governance. Doctoral dissertations. Tianjin University.2016.

[7] Yan Hu,xiaole Duan.Research on the position and responsibility of vocational colleges in the modern apprenticeship system. Journal of Chinese Training.2016 (7).

[8] Yan $\mathrm{Hu}$,Positioning and feasibility analysis of the integration of modern industry apprenticeship curriculum development. Journal of Contemporary Vocational Education.2016 (8).

[9] $\mathrm{Su} \mathrm{Li}$. Research on the application of modern apprenticeship in higher vocational colleges. Master's degree thesis. Guangdong Polytechnic Normal University.2016. 